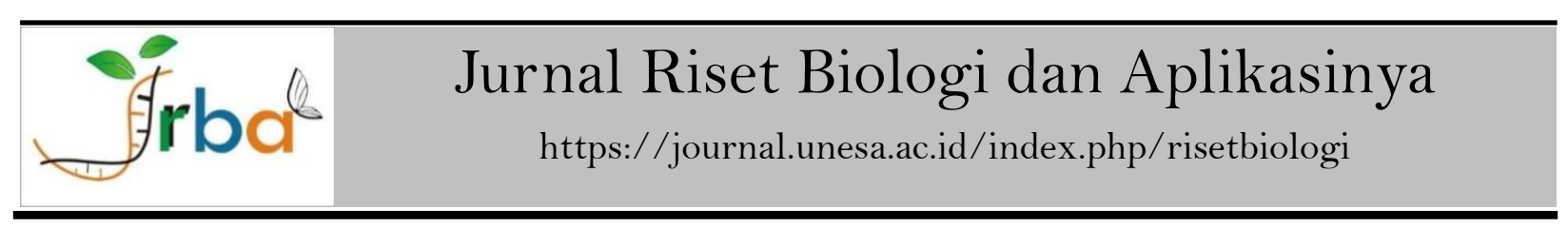

\title{
Optimasi Waktu Induksi dalam Mengekspresikan Gen Proinsulin secara Intraseluler Menggunakan Inang Pichia pastoris
}

\author{
Induction Time Optimation of Intracellular Proinsulin Gene Expression \\ Using Pichia pastoris as the Host
}

Efrida Martius ${ }^{1}$, Febraska Laoditta ${ }^{2}$, Dewi Yustika Sofia ${ }^{2}$, Anis Herliyati Mahsunah ${ }^{1}$ ${ }^{1}$ Balai Bioteknologi, Badan Pengkajian dan Penerapan Teknologi (BPPT) Gedung 630, ${ }^{2}$ Universitas Surya,

\section{Article History}

Received : 5 November 2019 Approved : 13 Februari 2020 Published : 31 Maret 2020

Kata Kunci: Proinsulin, Pichia pastoris, Diabetes, Ekspresi, Intraseluler

Keywords: Proinsulin, Pichia pastoris, Diabetes, Expression, Intracellular.

\begin{abstract}
Abstrak
Gen proinsulin telah berhasil diinsersi pada galur Pichia pastoris X33, GS115 dan KM71H pada penelitian sebelumnya, namun masih memerlukan optimasi. Penelitian ini dilakukan untuk mengetahui ekspresi galur $P$. pastoris dan waktu induksi yang optimal dalam mengekspresikan proinsulin. Ekspresi proinsulin dilakukan pada suhu $20{ }^{\circ} \mathrm{C}$ selama 120 jam untuk pemilihan galur terbaik. Variasi lama induksi yang digunakan adalah $0,24,48,72,96,120$ dan 144 jam untuk mengetahui waktu induksi optimal. Kultur kemudian dilisis, dielektroforesis menggunakan Tricine SDS PAGE dan divisualisasikan dengan pewarnaan perak. Berdasarkan ketebalan pita yang terbentuk pada gel elektroforesis, galur X33-X2 menghasilkan proinsulin terbanyak dibandingkan GS115-G11 dan KM71H-K4.. Ekspresi proinsulin optimal pada 120 jam dan mengalami penurunan proinsulin pada waktu induksi 144 jam akibat akumulasi metanol. Galur X33-X2 merupakan inang terbaik dan waktu induksi 120 jam merupakan waktu induksi optimal dalam mengekspresikan proinsulin secara intraseluler. Hasil ini diharapkan dapat menjadi referensi dalam mengembangkan produksi insulin di Indonesia.
\end{abstract}

How to cite: Martius, E., Laoditta, F., Sofia, D.Y., \& Mahsunah, A.H. (2020). Optimasi Waktu Induksi dalam Mengekspresikan Gen Proinsulin secara Intraseluler Menggunakan Inang Pichia pastoris. Jurnal Riset Biologi dan Aplikasinya, 2(1), 26-35.

* * Corresponding Author: e-ISSN 2655-9927

Jln. Kw. Puspiptek, Muncul, Serpong, Kota Tangerang Selatan, Banten 15314

E-mail: efrida.martius@bppt.go.id 


\section{PENDAHULUAN}

Diabetes melitus merupakan kelainan metabolik akibat kurangnya sekresi insulin, rusaknya fungsi insulin atau keduanya yang ditandai dengan hiperglikemia (Kharroubi \& Darwish, 2015). Total penderita diabetes di Indonesia mencapai lebih dari 10,2 juta pada tahun 2017 (IDF, 2018) dan diprediksi akan meningkat menjadi 21 juta penderita pada tahun 2030. Sebanyak 10-15\% penderita diabetes membutuhkan insulin dalam menjaga kadar glukosa darah dan mencegah komplikasi, namun ketersediaan insulin di Indonesia terbatas (WHO, 2016). Kebutuhan insulin ini mendorong adanya produksi insulin. Produksi insulin pada tubuh manusia dimulai dari transkripsi mRNA preproinsulin dari nukleus menjadi preproinsulin, kemudian preproinsulin dipotong oleh enzim peptidase menjadi proinsulin (Tokarz et al., 2018). Proinsulin yang telah terkonformasi menuju badan golgi untuk dipotong dan menghasilkan insulin dan peptida-C (Steiner et al., 1972). Namun, karena adanya kelainan fungsi/ produksi insulin dalam tubuh, hal ini mendorong adanya produksi insulin dilakukan dengan teknologi DNA rekombinan.

Goeddel et al. (1979) berhasil memproduksi insulin dengan menggabungkan rantai insulin-A dan insulin-B yang diproduksi oleh Escherichia coli. Produksi insulin dengan teknik lain juga dilakukan oleh Moore et al. (1983) yang berhasil mengintroduksi cDNA proinsulin pada sel sekresi hormon adenokortikotrofik (ACTH) untuk produksi proinsulin dan mengetahui mekanisme konversi proinsulin menjadi insulin. Penemuan ini memberikan kemudahan bagi industri farmasi dalam meningkatkan purifikasi insulin hasil ekstraksi dari hewan dan produksi insulin manusia (Philipson et al., 2015). Produksi proinsulin dapat menggunakan berbagai inang, salah satunya adalah ragi Pichia pastoris yang mampu memproduksi protein heterologous tanpa hiperglikosilasi (Grinna \& Tschopp, 1988). Selain itu, P. pastoris juga mampu memproduksi lebih dari 15 gram protein rekombinan dari 1 liter kultur secara intraseluler (Hasslacher et al., 1997) sehingga dapat digunakan untuk produksi skala besar.

Pichia pastoris dikembangkan untuk menghasilkan protein rekombinan dengan sistem ekspresi yang menggunakan promotor kuat AOX1 (Cregg et al., 1985). Promotor ini ditekan dengan keberadaan glukosa, gliserol dan etanol (Inan \& Meagher, 2001). Akan tetapi, akan dilepaskan saat diinduksi metanol (Cregg et al., 1985). Keberadaan metanol mengaktivasi faktor transkripsi methanol expression regulator 1 (Mxr1) yang berada di sitoplasma untuk masuk ke dalam nukleus dan berikatan dengan promotor AOX1 sehingga gen protein rekombinan dan gen AOX ditranskripsi (Zhan et al., 2017). Enzim AOX mengoksidasi metanol menjadi formaldehida dan hidrogen peroksida. Formaldehida yang dihasilkan kemudian dioksidasi menjadi format dan karbon dioksida oleh dehidrogenase di sitoplasma sebagai sumber energi bagi sel untuk tumbuh (Cereghino \& Cregg, 2000). Berdasarkan kemampuannya dalam memetabolisme metanol, $P$. pastoris dibedakan menjadi tiga jenis (Macauley-Patrick et al., 2005). Mut ${ }^{+}$merupakan fenotipe yang dapat tumbuh dalam metanol dengan laju perkembangan wild-type dan membutuhkan asupan metanol yang tinggi dalam fermentasi skala besar (Aoki et al., 2003). Muts merupakan fenotipe yang lambat dalam memetabolisme metanol karena memiliki gen AOX1 yang terganggu, sehingga bergantung pada promotor AOX2 yang lebih lemah dalam memetabolisme metanol (Cregg et al., 1987). Mut- tidak mampu tumbuh dalam metanol karena tidak memiliki kedua promotor (Cregg et al., 1987). Penelitian oleh Krainer et al. (2012) menyatakan

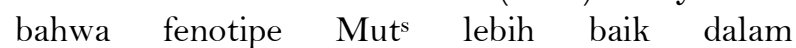
mengekspresikan protein rekombinan berupa horseradish peroksidase $\mathrm{C} 1 \mathrm{~A}$ dibandingkan fenotipe $\mathrm{Mut}^{+}$dalam produktivitas dan efisiensi ekspresi. Secara umum, fenotipe $\mathrm{Mut}^{+}$memiliki pertumbuhan yang cepat sedangkan fenotipe $\mathrm{Mut}^{\mathrm{s}}$ memiliki produktivitas yang lebih tinggi (Chirovulu et al., 1997).

Pichia pastoris mampu mengekspresikan protein rekombinan secara intraseluler dan ekstraseluler (Invitrogen, 2010). Menurut Yin et al. (2012), yield protein intraseluler lebih banyak dibandingkan ekstraseluler. Ekspresi proinsulin intraseluler berhasil dilakukan Triyadi (2018) menggunakan $P$. pastoris galur X-33, GS115 dan KM71H. Galur $P$. pastoris yang menghasilkan proinsulin paling banyak adalah GS115 pada lama induksi 72 jam dan suhu $25^{\circ} \mathrm{C}$ menggunakan konsentrasi akhir metanol 0,5\% (v/v). Menurut Cos et al. (2006) suhu rendah mampu meningkatkan produktivitas protein rekombinan sehingga menghasilkan protein rekombinan lebih banyak dibandingkan suhu tinggi. Oleh sebab itu, tujuan penelitian ini adalah untuk mengetahui galur $P$. pastoris yang mampu mengekpsresi proinsulin secara intraseluler paling banyak pada suhu $20{ }^{\circ} \mathrm{C}$ dan menentukan waktu induksi optimalnya. 


\section{BAHAN DAN METODE}

Alat yang digunakan dalam penelitian ini antara lain; autoklaf, cawan petri (90 x $15 \mathrm{~mm})$, tips mikropipet, eppendorf 1,5 dan $2 \mathrm{ml}$, mikropipet 2-20 $\mu \mathrm{l}$, mikropipet 20-200 $\mu \mathrm{l}$, Mikropipet 100-1000 $\mu \mathrm{l}$, tabung falkon, spatula, wadah timbang, neraca analitik, laminar UV, jarum ose, pipet ukur $25 \mathrm{ml}$, erlenmeyer $100 \mathrm{ml}$, pengaduk magnetik, hotplate, inkubator orbital, inkubator, inkubator goyang, spektrofotomer UV, kuvet spektrofotometer, botol schott $250 \mathrm{ml}$ dan $500 \mathrm{ml}$, High Speed Refrigerated Microcentrifuge, gelas ukur $100 \mathrm{ml}$, vortex, perangkat SDS-PAGE, power SDS-PAGE, ultrapure water system, membran filter $0,2 \mu \mathrm{m}$, pemindai, $\mathrm{pH}$ meter, lemari pendingin, lemari pembeku, tabung reaksi, plastic wrap, suntikan syringe dan $0,5 \mathrm{~mm}$ glass beads.

Bahan yang digunakan dalam penelitian ini, antara lain: ekstrak ragi (HIMEDIA), pepton teknis, d-glukosa (Merck), agar bakteri (Oxoid), asam klorida ( $\mathrm{HCl}), \mathrm{dH} 2 \mathrm{O}$, zeocin (Invitrogen), gliserol (Calbiochem), amonium sulfat (JT. Baker), yeast nitrogen tanpa asam amino dan amonium sulfat (JT. Baker), biotin (SIGMA), metanol (Merck), l-histidin (BIO BASIC Canada Inc.), alkohol 70\%, kalium dihidrogen fosfat $\left(\mathrm{KH}_{2} \mathrm{PO}_{4}\right)$ (JT. Baker), dikalium fosfat $\left(\mathrm{K}_{2} \mathrm{HPO}_{4}\right)$ (EMSURE), kasa, tali, kapas, aluminium foil (Total Wrap), tris (AppliChem), tricine buffer (BIO BASIC CANADA, INC.), SDS (Bio Basic Inc.), coomasie brilliant blue-R250 (Merck), akrilamida (Merck), bis-akrilamida (Promega, USA), dithiothreitol (DTT) (Promega, Kanada), amonium persulfat (Promega, USA), fenilmetanasulfonil fluorida (PMSF) (MP. Biomedicals, LLC., Paris), asam etilenadiaminatetraasetat (EDTA) (AppliChem), sodium dihidrogen fosfat $\left(\mathrm{NaH}_{2} \mathrm{PO}_{4}\right)$ (Merck), disodium hidrogen fosfat $\left(\mathrm{Na}_{2} \mathrm{HPO}_{4}\right)$ (Merck), DROW, air miliQ, tetrametietilendiamin (TEMED) (Merck), amonium hidrogen karbonat $\left(\left(\mathrm{NH}_{4}\right)_{2} \mathrm{CO}_{3}\right)$ (Merck), etanol absolut (Merck), asam asetat glasial (Merck), natrium trisulfat $\left(\mathrm{Na}_{2} \mathrm{~S}_{2} \mathrm{O}_{3}\right)$ (JT. Baker), perak nitrat $\left(\mathrm{AgNO}_{3}\right)$ (Agu Cicca Reagent), kalium karbonat $\left(\mathrm{K}_{2} \mathrm{CO}_{3}\right)$ (JT. Baker), formalin 37\%, $\beta$-mercaptoetanol (MP. Biomedicals), coomasie protein assay reagent $950 \mathrm{ml}$ (Thermo Scientific).

Komposisi media yang digunakan digunakan adalah Yeast extract peptone dextrose medium $(\mathrm{YPD})+$ Agar Zeocin $=1 \%$ ekstrak ragi $(\mathrm{m} / \mathrm{v}), 2 \%$ pepton $(\mathrm{m} / \mathrm{v}), 2 \%$ d-glukosa $(\mathrm{m} / \mathrm{v}), 2 \% \operatorname{agar}(\mathrm{m} / \mathrm{v})$, $100 u g / m l$ zeocin. Buffered Glycerol-complex Medium $(\mathrm{BMGY})=1 \%$ ekstrak ragi $(\mathrm{m} / \mathrm{v}), 2 \%$ pepton (m/v), $100 \mathrm{mM}$ kalium fosfat, $\mathrm{pH}$ 6,0 (v/v), 1, 34\%
YNB (v/v), $4 \quad \mathrm{x} \quad 10^{-5} \%$ biotin (v/v). $\operatorname{BMM}(\mathrm{H})$ $($ Buffered minimal $)=100 \mathrm{mM}$ kalium fosfat, $\mathrm{pH} 6,0$ (v/v), 1,34\% YNB (v/v), 4 X 10-5\% biotin (v/v), 0,5\% metanol (v/v), $100 \mathrm{X} \mathrm{H}(\mathrm{v} / \mathrm{v})$.

Komposisi larutan yang digunakan dalam fermentasi yaitu Gliserol 30\% $=15 \mathrm{ml}$ Gliserol $100 \%$ dalam $50 \mathrm{ml}$ air. $1 \mathrm{M}$ Kalium fosfat $\mathrm{pH} \mathrm{6,0=}$ 9,5 gram $\mathrm{KH}_{2} \mathrm{PO}_{4}$ dan 5,25 gram $\mathrm{K}_{2} \mathrm{HPO}_{4}$ dalam $100 \mathrm{ml}$ air, $\mathrm{pH}$ diatur dengan penambahan $\mathrm{HCl}$. YNB $13,4 \%=3,4$ gram YNB tanpa amonium sulfat dan asam amino, dan 10 gram amonium sulfat dalam $100 \mathrm{ml}$ air, filter steril. $0,02 \%$ biotin $(500 \mathrm{X} \mathrm{B})$ $=20 \mathrm{mg}$ biotin dalam $100 \mathrm{ml}$ air, filter steril. $100 \mathrm{x} \mathrm{H}$ $=400 \mathrm{mg}$ L-histidin dalam $100 \mathrm{ml}$ air, filter steril

Buffer yang digunakan untuk lisis sel dan elektroforesis Tricine SDS-PAGE adalah Breaking buffer $=50 \mathrm{mM}$ Sodium fosfat, $\mathrm{pH} 7,4,1 \mathrm{mM}$ PMSF, $1 \mathrm{mM}$ EDTA, 5\% gliserol. 2x Tricine Sample Buffer $=150 \mathrm{mM}$ Tris-HCl, pH 7,0, 30\% gliserol, $12 \%$ SDS, 0,05\% Coomasie Brilliant Blue R-250, 6\% $\beta$-mercaptoetanol. Bufer Katoda $1 \mathrm{x}=0,1 \mathrm{M}$ Tris, 0,1 M Trisin, 0,1\% SDS. Bufer Anoda $10 \mathrm{x}=0,2 \mathrm{M}$ Tris, $\mathrm{HCl}$ hingga $\mathrm{pH} 8,9$. Bufer Gel $3 \mathrm{x}=3 \mathrm{M}$ Tris, o,3\% SDS, $\mathrm{HCl}$ hingga $\mathrm{pH} 8,45$

Larutan yang diperlukan dalam elektroforesis Tricine SDS-PAGE sebagai berikut: Larutan AB-3 $=48$ gram akrilamid dan 1,5 gram bis-akrilamid dalam $100 \mathrm{ml}$ air miliQ. Larutan AB-6 = 46,5 gram akrilamid dan 3 gram bis-akrilamid dalam $100 \mathrm{ml}$ air miliQ. Larutan Gliserol 50\% $=30 \mathrm{ml}$ gliserol $85 \%$ dalam $50 \mathrm{ml}$ air miliQ. Larutan APS 10\% = 0,1 gram amonium persulfat dalam $2 \mathrm{ml}$ air miliQ. Larutan Fiksasi $=0,78$ gram amonium asetat ditambah $50 \mathrm{ml}$ metanol, $10 \mathrm{ml}$ asam asetat dan 40 $\mathrm{ml}$ air miliQ. Larutan Staining = 0,05 gram Coomasie Brilliant Blue R250 ditambah $20 \mathrm{ml}$ asam asetat glasial dan $180 \mathrm{ml}$ air miliQ. Larutan Destaining = $20 \mathrm{ml}$ asam asetat glasial ditambah $180 \mathrm{ml}$ air miliQ. Larutan Tris-HCl 0,5 M pH 7,0 = 6,057 gram tris ditambah $80 \mathrm{ml}$ air dan diatur $\mathrm{pH}$ dengan $\mathrm{HCl}$. Larutan Sodium fosfat $50 \mathrm{mM}, \mathrm{pH} 7,4=0,24$ gram sodium fosfat (monobasic) dalam $40 \mathrm{ml}$ air miliQ, diatur $\mathrm{pH}$ dengan $\mathrm{NaOH}$

Larutan yang dibutuhkan dalam pewarnaan perak sebagai berikut: Larutan amonium hidrogen karbonat $=0,2$ gram amonium hidrogen karbonat dalam $25 \mathrm{ml}$ metanol dan $25 \mathrm{ml}$ air miliQ. Larutan fiksasi $30 \%$ etanol, $10 \%$ asam asetat $=15 \mathrm{ml}$ etanol absolut ditambah $5 \mathrm{ml}$ asam asetat dan $30 \mathrm{ml}$ air miliQ. Larutan bilas 30\% etanol $=15 \mathrm{ml}$ etanol absolut dalam $35 \mathrm{ml}$ air miliQ. Larutan sensitasi 0,8 $\mathrm{mM} \mathrm{Na} \mathrm{N}_{2} \mathrm{~S}_{2} \mathrm{O}_{3}=0,0064$ gram $\mathrm{Na}_{2} \mathrm{~S}_{2} \mathrm{O}_{3}$ dalam $50 \mathrm{ml}$ air miliQ. Larutan $12 \mathrm{mM} \mathrm{AgNO}_{3}=0,1$ gram 
$\mathrm{AgNO}_{3}$ dalam $50 \mathrm{ml}$ air miliQ. Larutan developer $0,01 \% \mathrm{~K}_{2} \mathrm{CO}_{3}, 10 \% \mathrm{Na}_{2} \mathrm{~S}_{2} \mathrm{O}_{3}$, formalin = 1,5 gram $\mathrm{K}_{2} \mathrm{CO}_{3} 6,25 \mu \mathrm{l} \mathrm{Na} \mathrm{S}_{2} \mathrm{O}_{3}, 14 \mu \mathrm{l}$ formalin $37 \%$ dalam $50 \mathrm{ml}$ air miliQ. Larutan stop $4 \%$ tris, $2 \% \mathrm{HAc}=2$ gram tris, $1 \mathrm{ml}$ asam asetat glasial dalam $49 \mathrm{ml}$ air miliQ.

Tahapan pertama dilakukan fermentasi galur P. pastoris berupa X33 koloni 2 (X33-X2), GS115 koloni 11 (GS115-G11) dan KM71H koloni 4 (KM71H-K4) yang berasal dari stok kultur BPPT diregenerasi dengan menggoreskan pada media padat Yeast extract Peptone Dextrose (YPD) yang mengandung antibiotik zeocin dan diinkubasi selama 48 jam. Koloni tunggal dikultivasi dalam media kultivasi Buffered Glycerol-complex (BMGY) dan diinkubasi dengan suhu $30{ }^{\circ} \mathrm{C}$ dan kecepatan 250 rpm selama 16-18 jam. Setelah itu, biomassa $P$. pastoris diukur dengan spektrofotometer pada absorbansi $600 \mathrm{~nm}$ hingga mencapai nilai 2-6. Kultur dipindahkan ke dalam tabung falkon steril dan disentrifugasi dengan kecepatan $6.000 \mathrm{~g}$ selama 5 menit pada suhu $4{ }^{\circ} \mathrm{C}$, supernatan dibuang dan pelet dipindahkan ke media ekspresi Buffered Minimal (BMM(H). Setelah itu, kultur ditambahkan metanol hingga mencapai konsentrasi akhir 0,5\% $(\mathrm{v} / \mathrm{v})$ dalam media setiap 24 jam pada suhu $20{ }^{\circ} \mathrm{C}$. Setelah 120 jam, kultur disentrifugasi dengan kecepatan $12.000 \mathrm{~g}$ selama 5 menit pada suhu $4{ }^{\circ} \mathrm{C}$, supernatan dibuang dan pelet disimpan.

Pelet ditambahkan Breaking Buffer dengan perbandingan 1:1 (berat pelet: volume breaking buffer) dan diresuspensi. Setelah itu, ditambahkan glass beads dengan perbandingan 1:1 (berat pelet: berat glass beads) dan divorteks dengan $12.000 \mathrm{~g}$ selama 30 detik. Lalu, diinkubasi selama 30 detik dalam es dan dilakukan $8 \mathrm{x}$ pengulangan. Hasil resuspensi kemudian disentrifugasi dengan kecepatan $12.000 \mathrm{~g}$ selama 10 menit dan supernatan dipisahkan. Supernatan ditambahkan dengan 2x Tricine Sample Buffer dengan perbandingan 1:3 dan diinkubasi dalam waterbath dengan suhu $37{ }^{\circ} \mathrm{C}$ selama 15 menit. Setelah itu, sampel dimasukkan ke dalam sumur gel SDS-PAGE dan elektroforesis dijalankan dengan tegangan 30 volt selama 1 jam, selanjutnya dengan tegangan 90 volt hingga mencapai batas akhir. Setelah itu, gel diinkubasi dalam larutan fiksasi selama 1 jam, dalam larutan staining selama $1 \mathrm{jam}$, dan destaining hingga gel menjadi bening.

Gel yang telah diwarnai dibilas terlebih dahulu dengan air miliQ selama 5 menit dan dilakukan 2 kali pengulangan. Kemudian direndam dalam larutan $50 \mathrm{mM}$ amonium hidrogen karbonat selama
45 menit dan dibilas dengan air miliQ selama $2 \times 5$ menit. Setelah itu, gel direndam dalam larutan fiksasi selama 30 menit, diinkubasi dengan larutan $30 \%(\mathrm{v} / \mathrm{v})$ etanol selama $2 \times 10$ menit dan dibilas dengan air miliQ selama $2 \times 10$ menit. Selanjutnya, gel diinkubasi dalam $0,8 \mathrm{mM}$ selama 1 menit dan dibilas kembali dengan air miliQ selama 2 x 1 menit. Gel kemudian diinkubasi dengan larutan $12 \mathrm{mM}$ $\mathrm{AgNO}_{3}$ selama 20 menit dan dibilas dengan air miliQ selama 10 detik. Setelah itu, gel diinkubasi dalam larutan developer dengan penambahan formalin hingga kontras warna yang diinginkan. Kemudian gel dibilas dengan air miliQ selama 10 detik. Pewarnaan gel dihentikan dengan perendaman dalam larutan stop selama 30 menit dan dibilas dengan air miliQ selama 2 x 30 menit.

Nilai Rf digunakan untuk menghitung bobot molekul dengan membandingkan kurva linear antara nilai $\mathrm{Rf}$ terhadap $\log$ bobot molekul. Perhitungan nilai Rf adalah sebagai berikut.

$$
\text { Nilai } R f=\frac{\text { Jarak pita dengan batas atas gel SDS }}{\text { Jarak seluruh gel SDS }}
$$

Setelah nilai $\mathrm{Rf}$ diplot dengan $\log$ berat molekul marka protein dan didapatkan persamaan, nilai Rf pita target dihitung berdasarkan persamaan tersebut sehingga mendapatkan nilai log berat molekul protein target. Antilog nilai tersebut merupakan berat molekul protein target.

Hasil scan dari gel SDS-PAGE dengan format .jpeg dikuantifikasi menggunakan program ImageJ 1.51j8 dengan memotong gambar yang melingkupi daerah pita yang diinginkan dengan fitur rectangular selection kemudian mengklik crop. Area yang diseleksi dianalisis dengan mengklik Analyze dan diulangi hingga seluruh pita dianalisis sehingga akan muncul beberapa plot secara bersusun. Pada masing-masing plot terdapat garis yang menggambarkan peak sehingga ditarik garis antara pangkal awal dan pangkal ujung menggunakan straight line. Setelah itu, area dalam peak dihitung menggunakan wand (tracing) tool dan kotak Result akan muncul menggambarkan luas area pita yang diseleksi.

\section{HASIL DAN PEMBAHASAN}

Hasil visualisasi insulin standar menunjukkan adanya 2 pita, seperti pada Gambar 1. Pada penelitian ini, insulin standar yang digunakan merupakan produk komersial Humulin Eli Lilly. Insulin manusia dengan rumus empiris $\mathrm{C}_{257} \mathrm{H}_{383} \mathrm{~N}_{62} \mathrm{O}_{77} \mathrm{~S}_{6}$ memiliki bobot molekul $5808 \mathrm{Da}$ (Lilly, 2018). Pita yang lebih tipis di atas insulin 
standar merupakan proinsulin standar karena mengandung jumlah yang lebih sedikit dibandingkan insulin standar. Regulasi FDA memperbolehkan insulin komersial untuk mengandung kurang dari 10 ppm proinsulin dan residu lain yang berkaitan dengan insulin (Bohannon, 1983). Menurut Binder et al. (1996), insulin manusia komersial telah bebas dari kontaminan residu, namun dapat mengandung $<1$ ppm atau $1 \mathrm{mg} / \mathrm{L}$ proinsulin. Oleh karena itu, pita yang terbentuk di atas insulin standar merupakan proinsulin standar. Penggunaan pewarnaan perak yang dapat mendeteksi protein dalam jumlah nanogram juga dapat memvisualisasikan proinsulin dengan kadar rendah.

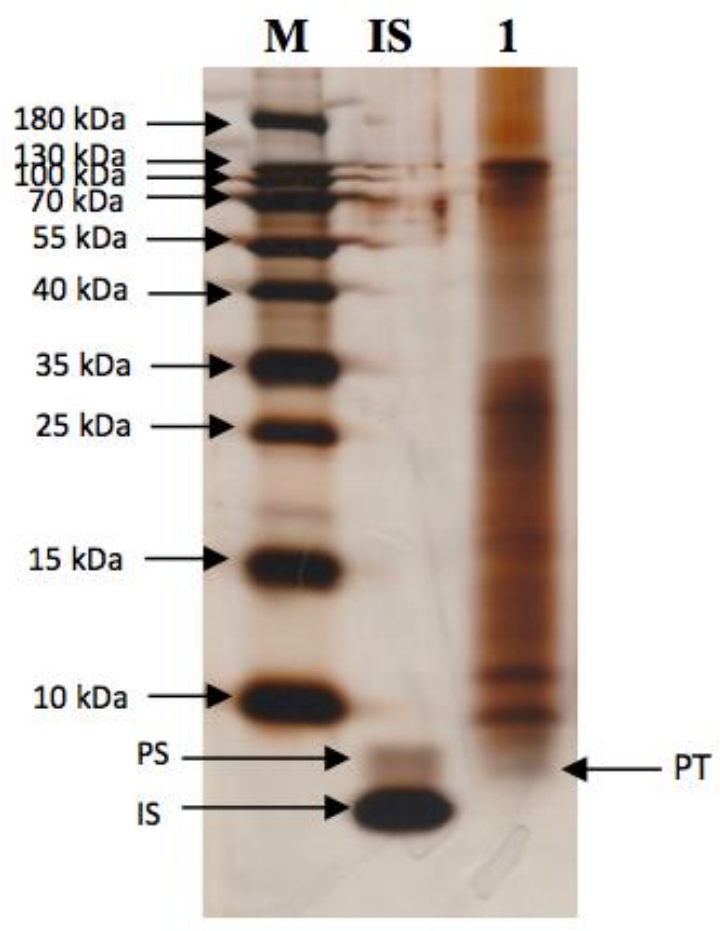

Gambar 1. Visualisasi protein target. $M=$ marka protein 10-180 $\mathrm{kDa}$, IS = standar insulin, $1=$ Galur X33-X2, PT = proinsulin target. Hasil fermentasi $P$. pastoris $\mathrm{X} 33-\mathrm{X} 2$ pada suhu ekspresi $20{ }^{\circ} \mathrm{C}$, metanol $0,5 \%$ setiap 24 jam sekali selama 120 jam. Pita PT terdapat di antara pita marka protein $10 \mathrm{kDa}$ dan insulin standar 5808 Da.

Hasil perhitungan BM proinsulin standar (PS), insulin standar (IS) dan proinsulin target (PT) ditunjukkan pada Tabel 1. Nilai Rf pita PT dimasukkan dalam persamaan dan BM yang dihasilkan adalah 6761 Da. Pita PT berada di antara PS dan IS. IS memiliki BM 5808 Da secara teoretis, akan tetapi hasil dengan perbandingan nilai $\mathrm{Rf}$ adalah 6165 Da. Perbedaan perhitungan ini dapat terjadi karena pita IS dan pita target berada di luar marka $10-70 \mathrm{kDa}$. Perhitungan BM menjadi akurat apabila sampel protein berada pada jarak linear dari kurva standar. Kesalahan perhitungan sebesar \pm 10\% dapat diterima (Matsumoto et al., 2018).

Tabel 1. Bobot molekul proinsulin dan insulin standar (PS dan IS) serta protein target (PT) hasil fermentasi $P$. pastoris X22-X3 berdasarkan Nilai Rf

\begin{tabular}{cccc}
\hline & PS & IS & PT \\
\hline Nilai Rf & 0,76 & 0,80 & 0,77 \\
BM (Da) & 7079 & 6165 & 6761 \\
\hline
\end{tabular}

$\mathrm{R}^{2}=0.989 . \mathrm{PS}=$ proinsulin standar, $\mathrm{IS}=$ insulin standar, $\mathrm{PT}=$ proinsulin target. Nilai Rf terhadap bobot molekul PS, IS dan PT pada gel Gambar 4.3. dan memiliki kesalahan perhitungan $\leq 10 \%$.

Ketidaksamaan BM pita PT dan PS dapat terjadi akibat variasi antar protein, seperti struktur protein, perbedaan hasil pascatranslasi dan komposisi asam amino yang mempengaruhi migrasi elektroforesis (Zahid et al., 2014). Selain itu, jenis produksi PS juga tidak diketahui, seperti ekspresi ekstraseluler atau intraseluler dan bagaimana urutan sekuen yang digunakan. Protein ekstraseluler memiliki komposisi yang lebih kompleks daripada intraseluler untuk menghalangi proses pelipatan protein karena protein yang disekresi harus dalam bentuk belum dilipat. Polipeptida hidrofobik dan bermuatan kecil pada protein ekstraseluler memudahkan protein untuk transpor keluar membran (Nakashima \& Nishikawa, 1994). Komposisi yang lebih kompleks dapat menyebabkan protein yang dihasilkan secara ekstraseluler memiliki BM lebih tinggi dibandingkan intraseluler. Urutan sekuen yang tidak mengikuti Gurramkonda et al. (2010) mempengaruhi asam amino yang dihasilkan sehingga BM yang dihasilkan tidak sama.

Pemilihan galur $P$. pastoris dilakukan pada suhu $20{ }^{\circ} \mathrm{C}$ dengan induksi metanol $0,5 \%(\mathrm{v} / \mathrm{v})$ setiap 24 jam sekali dengan waktu induksi 120 jam. Pada suhu $20{ }^{\circ} \mathrm{C}$, pita paling bawah dapat dihasilkan oleh seluruh inang Pichia pastoris X33-X2, GS115-G11, dan KM71H-K4. Visualisasi proinsulin hasil ekspresi $P$. pastoris X33-X2, GS115-G11 dan KM71H-K4 dapat dilihat pada Gambar 2. Pita yang terbentuk memiliki ketebalan yang berbeda-beda antara satu dengan yang lain. Akan tetapi, setelah dicermati, X33-X2 menghasilkan pita dengan ketebalan yang serupa pada tiga perlakuan, dibandingkan pada GS115-G11 dan KM711H-K4 yang memiliki ketebalan yang tidak sama pada tiga 
perlakuan. Hasil yang konstan ini menandakan bahwa kemampuan ekspresi X33-X2 konsisten, sedangkan kemampuan ekspresi GS115-G11 dan KM71H-K4 berbeda-beda. Pita yang terbentuk juga tidak memiliki letak yang sejajar, hal ini dapat terjadi akibat adanya "doublet" yang mengindikasikan adanya polipeptida dengan asam amino yang sama namun memiliki residu berlebih atau berbeda posisi, seperti isoform (Caprette, 2005). Modifikasi pasca translasi akibat fosforilasi atau glikosilasi mampu menambahkan komposisi asam amino sehingga dapat menambah BM protein target sehingga letak yang dihasilkan lebih tinggi daripada BM teoritis.

$M \quad$ IS X33-X2 GS115-G11 KM71H-K4 IS $\overbrace{}^{1} \begin{array}{llllllll}2 & 3 & 1 & 3 & 3 & 2 & 3\end{array}$

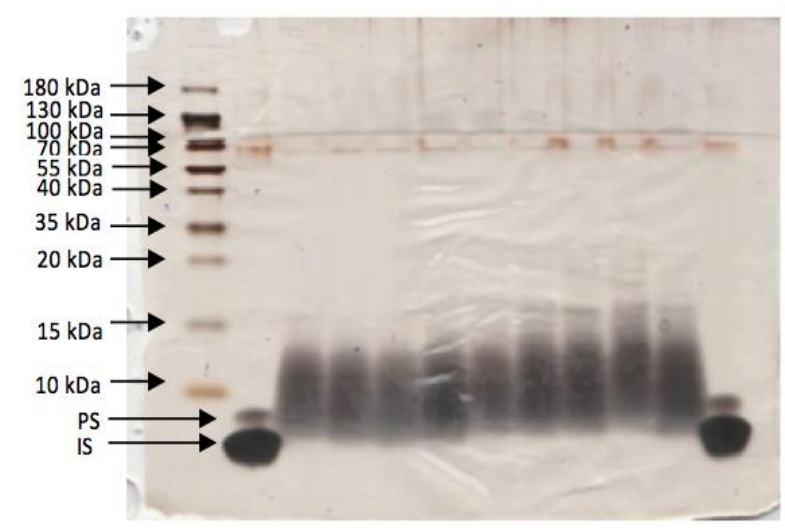

Gambar 2.Visualisasi hasil eskpresi proinsulin $P$. pastoris X33-X2, GS115-G11 dan KM71H-K4 secara intraseluler pada Suhu $20{ }^{\circ} \mathrm{C}$. Ekspresi proinsulin dilakukan dalam media $\operatorname{BMM}(\mathrm{H})$ pada suhu $20{ }^{\circ} \mathrm{C}$ dengan induksi metanol $0,5 \%$ setiap 24 jam selama 120 jam. Seluruh inang menghasilkan pita proinsulin target. X33-X2 menghasilkan ketebalan pita yang konstan dengan 3 pengulangan. Pita yang dihasilkan tidak sejajar akibat konsentrasi proinsulin atau adanya modifikasi pasca translasi sehingga bobot molekul berbeda

Nilai Rf marka kemudian dibandingkan dengan $\log$ BM marka dan menghasilkan persamaan $\mathrm{y}=$ 1,709x $+2,288$ dengan $\mathrm{R}^{2}=0,987$ dan hasil perhitungan BM terdapat pada Tabel 2. Nilai Rf pita marka dihitung menggunakan batas bawah pita karena pita PT tidak terbentuk sempurna (menjadi sebuah pita) melainkan menempel dengan protein lain di atasnya. Pita paling bawah yang dihasilkan P. pastoris X33-X2, GS115-G11 dan KM71H-K4 berada di antara pita PS dan IS, sehingga menandakan bahwa pita tersebut merupakan pita PT yang dihasilkan secara intraseluler. Akan tetapi, perhitungan nilai Rf pita paling bawah masingmasing galur menghasilkan BM yang berbeda.

Tabel 2. Bobot molekul PT Hasil Eskpresi seluruh inang $P$. pastoris pada suhu $20{ }^{\circ} \mathrm{C}$ berdasarkan Nilai Rf

\begin{tabular}{lcc}
\hline Sampel/Kolom & Nilai Rf & BM (Da) \\
\hline PS & 0,82 & 7762 \\
\hline IS & 0,9 & 5623 \\
\hline X33-X2/1 & 0,85 & 6760 \\
\hline X33-X2/2 & 0,86 & 6606 \\
\hline X33-X2/3 & 0,86 & 6606 \\
\hline GS115-G11/1 & 0,85 & 6760 \\
\hline GS115-G11/2 & 0,84 & 7079 \\
\hline GS115-G11/3 & 0,84 & 7079 \\
\hline KM71H-K4/1 & 0,84 & 7079 \\
\hline KM71H-K4/2 & 0,83 & 7413 \\
\hline KM71H-K4/3 & 0,85 & 6918
\end{tabular}

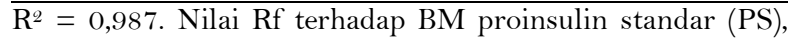
insulin standar (IS) dan proinsulin target (PT) pada gel Gambar 3. PT seluruh galur berada di antara PS dan IS. Proinsulin target X33-X2 pengulangan 1-3 dan GS115-G11 pengulangan 1 memiliki kesalahan perhitungan $\leq 10 \%$, sedangkan proinsulin target lainnya memiliki kesalahan perhitungan $>10 \%$. Perbedaan BM dapat disebabkan adanya "doublet" berupa isoform proinsulin.

Ketebalan pita yang dianalisis menggunakan ImageJ menghasilkan data luas area, ditunjukkan pada Tabel 3. X33-X2 memiliki rata-rata luas area yang paling tinggi dibandingkan GS115-G11 dan KM71H-K4. Ketebalan pita proinsulin X33-X2 terlihat konsisten dibandingkan GS115-G11 dan KM71H-K4. Oleh sebab itu, X33-X2 merupakan inang yang paling baik dalam menghasilkan proinsulin pada suhu ekspresi $20{ }^{\circ} \mathrm{C}$.

Optimasi waktu induksi dilakukan menggunakan inang $P$. pastoris $\mathrm{X} 33-\mathrm{X} 2$ sebagai inang terpilih pada suhu ekspresi $20{ }^{\circ} \mathrm{C}$ dalam menghasilkan proinsulin. Ekspresi proinsulin dilihat berdasarkan pita paling bawah (PT) yang tervisualisasi pada gel, seperti pada Gambar 3. Ekspresi proinsulin tidak terlihat pada o jam hingga 96 jam, namun terlihat ada penambahan variasi protein dan jumlah protein yang dihasilkan. Konsentrasi protein total yang digunakan saat elektroforesis telah disamakan, oleh sebab itu adanya pita yang lebih tebal dapat disebabkan variasi protein yang terekspresi seperti isoform atau protein dengan BM yang hampir sama. 
Tabel 3. Rata-rata luas area pemilihan inang menggunakan ImageJ

\begin{tabular}{ccc}
\hline Galur/Kolom & Luas Area & Rata-rata Luas Area \\
\hline $\mathrm{X} 33-\mathrm{X} 2 / 1$ & 2171.945 & \\
$\mathrm{X} 33-\mathrm{X} 2 / 2$ & 5237.011 & \\
$\mathrm{X} 33-\mathrm{X} 2 / 3$ & 3522.576 & \\
$\mathrm{GS} 115-\mathrm{G} 11 / 1$ & 4934.153 & \\
$\mathrm{GS} 115-\mathrm{G} 11 / 2$ & 2973.271 & 2914.187 \\
$\mathrm{GS} 115-\mathrm{G} 11 / 3$ & 835.137 & \\
$\mathrm{KM} 71 \mathrm{H}-\mathrm{K} 4 / 1$ & 1726.17 & \\
$\mathrm{KM} 71 \mathrm{H}-\mathrm{K} 4 / 2$ & 1103.158 & 2808.039 \\
$\mathrm{KM} 71 \mathrm{H}-\mathrm{K} 4 / 3$ & 5594.789 & \\
\hline
\end{tabular}

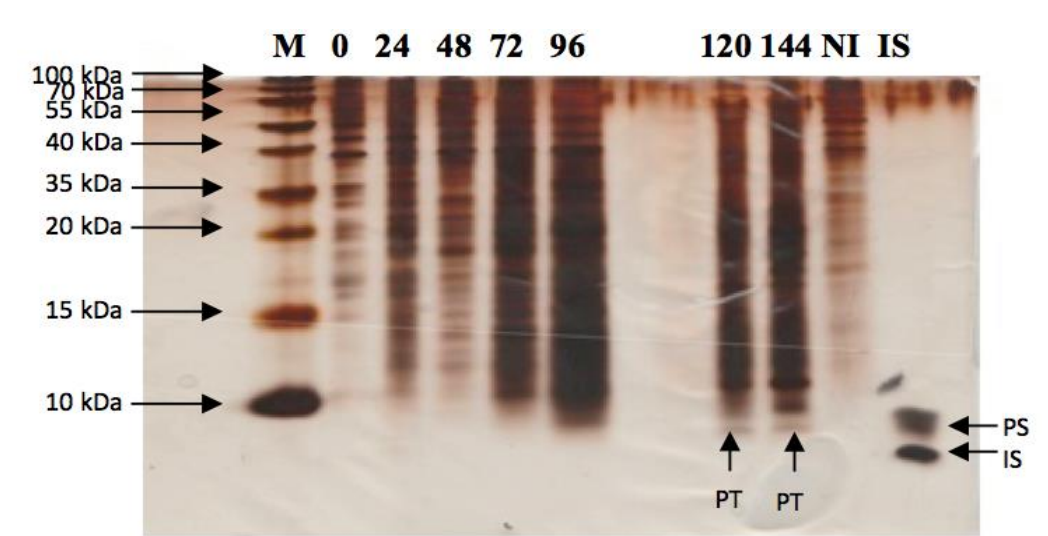

Gambar 3. Optimasi lama induksi dari P. pastoris X33-X2 pada Suhu Ekspresi $20{ }^{\circ} \mathrm{C}$. Keterangan gambar (kiri-kanan) M; marker, o jam, 24 jam, 48 jam, 72 jam, 96 jam, 120 jam, 144 jam, NI= X33-X2 non induksi, $\mathrm{IS}=$ insulin standar. $\mathrm{PS}=$ proinsulin standar, $\mathrm{PT}=$ proinsulin target. Ekspresi dilakukan menggunakan media BMM dengan induksi metanol 0,5\% setiap 24 jam selama 120 jam. Ekspresi proinsulin mulai terlihat pada lama induksi 120 jam dan 144 jam seperti ditunjukkan pada tanda panah ke atas.

Tabel 4. Bobot molekul proinsulin target hasil eskpresi inang $P$. pastoris $\mathrm{X} 33-\mathrm{X} 2$ pada suhu $20{ }^{\circ} \mathrm{C}$ lama induksi 120 Jam dan 144 Jam berdasarkan Nilai Rf

\begin{tabular}{cccc}
\hline & PS & IS & PT \\
\hline Nilai Rf & 0.72 & 0.80 & 0.77 \\
\hline BM (Da) & 7585 & 5754 & 6456 \\
\hline
\end{tabular}

$\overline{\mathrm{R}^{2}}=0,962$. Nilai Rf terhadap BM proinsulin standar (PS), insulin standar (IS) dan proinsulin target (PT). PT berada di antara PS dan IS. Kesalahan perhitungan $\leq 10 \%$ dari BM teoritis menandakan hasil dapat diterima.

Ekspresi proinsulin mulai terlihat pada lama induksi 120 jam dan 144 jam. Pita PT pada 120 jam dan 144 jam terbentuk sempurna (tidak menempel pada protein lain) dan ketebalan pita PT terlihat seragam. Oleh sebab itu, ketebalan pita diukur berdasarkan luas area yang dihitung menggunakan software ImageJ. Pita yang terpisah memudahkan dalam melihat ketebalan pita dengan software ImageJ dalam melihat peak pita.

Keberadaan pita dianalisis dengan memasukkan nilai Rf pada persamaan $y=-1,413 x+1,900$ dengan $\mathrm{R}^{2}=0,962$, hasil perbandingan nilai $\mathrm{Rf}$ dengan $\log$ BM marka protein. Setelah itu, BM pita yang merupakan PT ditunjukkan pada Tabel 4. Pita paling bawah dari hasil ekspresi $P$. pastoris $\mathrm{X} 33-\mathrm{X} 2$ pada lama induksi 120 jam dan 144 jam (6456 Da) berada di antara PS dan IS. Hal ini menandakan bahwa pita tersebut merupakan pita PT. Selain itu, kesalahan perhitungan $\leq 10 \%$ dari $\mathrm{BM}$ teoretis juga menandakan bahwa hasil ini dapat diterima.

Dalam menentukan lama induksi optimal, ketebalan pita dianalisis menggunakan software ImageJ berdasarkan luas area dari pita target seperti pada Tabel 5. Pita PT dengan lama induksi 120 jam memiliki luas area yang lebih tinggi dibandingkan 144 jam. Proinsulin mulai terekspresi pada lama induksi 120 jam dan menghasilkan pita yang paling tebal sehingga merupakan lama induksi yang optimal pada suhu $20^{\circ} \mathrm{C}$. Fermentasi dengan inang $P$. pastoris fenotipe mut ${ }^{\mathrm{s}}$ pada umumnya untuk 
mencapai konsentrasi protein rekombinan tinggi membutuhkan waktu yang lama, 150-200 jam (Vassileva et al., 2001). Mut ${ }^{\text {s }}$ memiliki tingkat konsumsi metanol dan pertumbuhan yang rendah sehingga membutuhkan waktu induksi yang panjang (Zhang et al., 2003).

Tabel 5. Hasil perhitungan luas area yang terbentuk pada 120 jam dan 144 jam berdasarkan ImageJ

\begin{tabular}{cc}
\hline Pita & Luas Area \\
\hline $120 \mathrm{jam}$ & 3617.530 \\
$144 \mathrm{jam}$ & 3178.045 \\
\hline
\end{tabular}

Keberadaan gliserol pada medium BMGY menekan promotor AOX1 untuk tidak mentranskripsi gen proinsulin. Sisa gliserol dalam sel saat dipindahkan ke medium ekspresi BMM membuat promotor AOX1 tertekan, namun seiring berjalannya waktu, ketidakberadaan gliserol dalam medium membuat sel harus beradaptasi dengan metanol (Chauhan et al., 1999).

Muts memetabolisme metanol dengan lambat karena memiliki gen AOX1 yang terganggu, sehingga bergantung pada promotor AOX2 yang lebih lemah dalam memetabolisme metanol (Cregg et al., 1987). Ekspresi proinsulin menjadi rendah saat 144 jam dapat disebabkan akumulasi metanol yang masih tersisa sehingga menjadi toksik pada sel dan mendegradasi proinsulin yang ada. Metanol dioksidasi menjadi formaldehida dan metanol peroksida oleh enzim AOX (Cereghino \& Cregg, 2000). Hidrogen peroksida menghasilkan stress oksidatif pada sel dan dapat memicu degradasi protein rekombinan (Hilt \& Wolf, 1992).

\section{SIMPULAN}

Inang $P$. pastoris $\mathrm{X} 33-\mathrm{X} 2$ merupakan inang yang mampu menghasilkan proinsulin secara intraseluler paling banyak dibandingkan GS115G11 dan KM71H-K4 pada suhu $20^{\circ} \mathrm{C}$. Ekspresi proinsulin optimal pada waktu induksi 120 jam. Waktu induksi yang panjang akibat aktivitas metabolik inang rendah sehingga kemampuan dalam memetabolisme metanol dan produksi protein rekombinan rendah.

\section{UCAPAN TERIMA KASIH}

Terima kasih kepada Balai Bioteknologi BPPT karena telah menyediakan tempat dan topik penelitian. Kepada Bapak Danang, Ibu Uli, Kakak Titin atas dukungan moral dan penyedia informasi berkaitan pengerjaan penelitian. Walbert Christian sebagai partner kerja laboratorium.

\section{DAFTAR PUSTAKA}

Aoki, H., Watabe, S., \& Ahsan, N. (2003). Heterologous expression in Pichia pastoris and single-step purification of a cysteine proteinase from northern shrimp. Protein Expression and Purification, 31(2), 213-221. doi: 10.1016/s 1046-5928(03)00196-7

Bohannon, N. J. V. (1983). Newer Forms of Insulin. The Western Journal of Medicine, 139(1), 115$116 . \quad$ Diakses dari https://www.ncbi.nlm.nih.gov/pmc/articles/P MC1010916/.

Cereghino, J. L., \& Cregg, J. M. (2000). Heterologous protein expression in the methylotrophic yeast Pichia pastoris. FEMS Microbiology Reviews, 24(1), 45-66. doi: https://doi.org/10.1111/j.15746976.2000.tb00532.x.

Chauhan, A. K., Arora, D., \& Khanna, N. (1999). A novel feeding strategy for enhanced protein production by fed-batch fermentation in recombinant Pichia pastoris. Process Biochemistry, 34(2), 139-145. Diakses dari http://agris.fao.org/agris-

search/search.do? recordID=US201302911699.

Cos, O., Ramon, R., Montesinos, J.L.,\& Valero F. (2006). Operational strategies, monitoring and control of heterologous protein production in the methylotrophic yeast Pichia pastoris under different promoters: A review. Microbial Cell Factories, 5(17), 1-20. doi: 10.1186/1475-28595-17

Cregg, J. M., Barringer, K. J., Hessler, A. Y., \& Madden, K. R. (1985). Pichia pastoris as a host system for transformations. Molecular and Celluler Biology, 5(12), 3376-3385. doi: 10.1128/mcb.5.12.3376.

Cregg, J. M., Tschopp, J. F., Stillman, C., Siegel, R., Akong, M., Craig, W. S., Buckholz, R. G., Madden, K. R., Kellaris, P. A., \& Davis, G. R. (1987). High-Level Expression and Efficient Assembly of Hepatitis-B Surface-Antigen in the Methylotrophic Yeast, Pichia pastoris. Nature Biotechnology, 5, 479-485. Diakses dari https://www.nature.com/articles/nbt0587479 .

Chiruvolu, V., Cregg, J. M., Meagher, M. M. 1997. Recombinant protein production in an alcohol oxidase-defective strain of Pichia pastoris in fed-batch fermentations. Enzyme and Microbiology Technology, 21(4), 277-283. doi: https://doi.org/10.1016/So1410229(97)00042-2.

Goeddel, D. V., Kleid, D. G., Bolivar, F., Heyneker, H. L., Yansura, D. G., Crea, R., Hirose, T., Kraszewski, A., Itakura, K., \& Riggs, A. D. (1979). Expression in Escherichia coli of chemically synthesized genes for human insulin. Proceedings of the National Academy of 
Science, 76(1), 106-110. doi: 10.1073/pnas.76.1.106

Grinna, L. S., \& Tschopp, J. F. (1989). Size distribution and general structural features of N-linked oligosaccharides from the methylotropic yeast Pichia pastoris. Yeast, 5(2), 107-115. doi: 10.1002/yea.320050206.

Gurramkonda, C., Polez, S., Skoko, N., Adnan, A., Gäbel, T., Chugh, D., \& Rinas, U. (2010). Application of simple fed-batch technique to high-level secretory production of insulin precursor using Pichia pastoris with subsequent purification and conversion to human insulin. Microbial Cell Factories, 9(31), 111. doi: 10.1186/1475-2859-9-31.

Hasslacher, M., Schall, M., Hayn, M., Bona, R., Rumbold, K., Lückl, J., Griengl, H., Kohlwein, S. D., \& Schwab, H. (1997). High-level intracellular expression of hydroxynitrile lyase from the tropical rubber tree Hevea brasiliensis in microbial hosts. Protein Expression Purification,11(1), 61-71. doi: 10.1006/prep.1997.0765.

Hilt., W., \& Wolf, D. H. (1992). Stress induced proteolysis in yeast. Molecular Microbiology, 6 (17), 2437-2442. doi:https://doi.org/10.1111/j.13652958.1992.tb01419.x.

International Diabetes Federation (IDF). (2018). IDF Western Pasific Members. Diakses pada 23 November 2018. https://www.idf.org.

Inan, M., \& Meagher, M. M. (2001). Non-repressing carbon sources for alcohol oxidase (AOX1) promoter of Pichia pastoris. Journal of Bioscience and Bioengginering. 92(6), 585-589. doi: 10.1016/S1389-1723(01)80321-2

Invitrogen. (2010). EasySelectTM Pichia Expression Kit: For Expression of Recombinant Proteins Using pPICZ and pPICZ in Pichia pastoris. Thermo Scientific.

Kharroubi, A. T., \& Darwish, H. M. (2015). Diabetes mellitus: The epidemic of the century. World Journal Diabetes, 6(6), 850-867. doi: 10.4239/wjd.v6.i6.850.

Krainer, F. W., Dietzsch, C., Hajek, T., Herwig, C., Spadiut, O., \& Glieder, A. (2012). Recombinant protein expression in Pichia pastoris strains with an engineered methanol utilization pathway. Microbiology Cell Factories, 11(22), 114. doi: 10.1186/1475-2859-11-22.

Lilly, E. (2018). Humulin. Eli Lilly and Company: Indianapolis.

Matsumoto, H., Hanlu, H., \& Komori, N. (2018). Determination of Protein Molecular Weights on SDS-PAGE. Electrophoretic Separation of Proteins, 1855, 101-105. Diakses dari https://link.springer.com/protocol/10.1007/9 78-1-4939-8793-1_10.
Macauley-Patrick, S., Fazenda, M. L., McNeil, B., \& Harvey, L. M. (2005). Heterologous protein production using the Pichia pastoris expression system. Yeast, 22(4), 249-270. doi: $10.1002 /$ yea. 1208

Moore, H. H., Walker, M. D., Lee, F., Kelly, R. B. 1983. Expressing a Human Proinsulin cDNA in a Mouse ACTH-Secreting Cell. Intracellular Storage, Proteolytic Processing, and Secretion on Stimulation. Cell, 35(2), 531-538. doi: 10.1016/0092-8674(83)90187-3.

Nakashima, H., \& Nishikawa, K. (1994). Discrimination of Intracellular and Extracellular Proteins Using Amino Acid Composition and Residue-pair Frequencies. Journal Molecular Biology, 238(1), 54-61. Diakses dari https://www.jsbi.org/pdfs/journal1/GIW94/ Poster/GIW94P18.pdf.

Philipson, L. H., Bell, G., \& Polonsky, K. S. (2015). Donald F. Steiner MD, 1930-2014: Discoverer of proinsulin. Restropective,. 112(4), 940-941. doi: https://doi.org/10.1073/pnas.1423774112.

Steiner, D. F., Peterson, J. D., Tager, H., Emdin, S., Ostberg, \& Y. Falkmer, S. 1973. Comparative Aspects of Proinsulin and Insulin Structure and Biosynthesis. Integrative and Comparative Biology, 13(3), 591-604. doi: https://doi.org/10.1093/icb/13.3.591.

Tokarz, V. L., MacDonald, P. E., Klip, A. 2018. The cell biology of systemic insulin function. Journal of Cell Biology, 217(7), 2273-2289. doi: 10.1083/jcb.201802095.

Martius, E., Triyadi, A., Yustika D., \& Mahsunah, A. H. (2019). Pengaruh Variasi Konsentrasi Metanol dan Lama Induksi terhadap Ekspresi Proinsulin oleh Pichia pastoris secara Intraseluler. Jurnal Bioteknologi dan Biosains Indonesia 6(1): 93-105.

Doi: http://dx.doi.org/10.29122/jbbi.v6i1.3176

Vassileva, A., Chugh, D. A., Swaminathan, S., \& Khanna, N. (2001). Effect of Copy Number on the Expression Levels of Hepatitis B Surface Antigen in the Methylotrophic Yeast Pichia pastoris. Protein Expression and Purification, 2 1(1), 71-80. doi: 10.1006/prep.2000.1335.

World Health Organization (WHO). (2016). Global Report on Diabetes. WHO: Geneva.

Yin, H., Liu, Z., Zhang, A., Zhang, T., Luo, J., Shen, J., Chen, L., Zhou, B., Fu, X., Fu, C., \& Zhang, Z. (2012). Intracellular expression and purification of the Canstatin-N protein in Pichia pastoris. Gene, 504(1): 122-126. doi: 10.1016/j.gene.2012.04.073.

Zahid, A., Jamil, W., \& Begum, R. (2014). Method Development and Validation of SDS-PAGE for Quality Control Testing of Pegylated Interferon Alpha-2a. IOSR Journal of Pharmacy 
and Biological Sciences, 9(6), 32-36. doi: 10.9790/3008-09643236.

Zhan, C., Yang, Y., Zhang, Z., Li, X., Liu, X., \& Bai, Z. (2017). Transcription factor Mxr1 promotes the expression of Aox 1 by repressing glycerol transporter 1 in Pichia pastoris. FEMS Yeast Res, 17(4), 1-10. doi: 10.1093/femsyr/fox015.
Zhang W. H., Potter K. J. H., Plantz B. A., Schlegel V. L., Smith L. A., \& Meagher M. M. (2003). Pichia pastoris fermentation with mixed-feeds of glycerol and methanol: growth kinetics and production improvement. Journal of Industrial Microbiology and Biotechnology, 30(4), 210-215. doi: $\quad 10.1007 / \mathrm{s} 10295-003-0035-3$. 